\title{
"ENFERMEIROS PARA O NORDESTE EM DESENVOLVIMENTO - ASSISTENCIA DE ENFERMAGEM E EDUCAÇÃO"
}

\section{Haydée Guanais Dourado}

- Tese de doutoramento e docência livre de Haydée Guanais Dourado, da Escola de Enfermagem Ana Neri da Universidade Federal do Rio de Janeiro, 1968. A tese é uma pesquisa social de enfermagem com os objetivos de averiguar

1) Se a assistência de enfermagem do tipo moderno está difundida no Recife, mudamos os tipos anteriores;

2) quais as evidências de achar-se institucionalizado o seguinte: o enfermeiro responsabilizar-se pela assistência de enfermagem e qual o grau dessa institucionalização;

3) que indicação surge como área para investigações futuras ou providências no sentido de apresentar-se a institucionalização da enfermagem moderna no caso de confirmar-se tal necessidade. gem no País, e do início dos serviços públicos de saúde.

$\mathrm{Na}$ Introdução, referiu-se que, para responder as indagações citadas, a autora, com a colaboração de onze enfermeiras, investigaram e preencheram um questionário, à vista de uma pessoa em autoridade, em 75 estabelecimentos (hospitais, ambulatórios e unidades sanitárias) do Recife, excluídos os militares, no total de cerca de 150 visitas. Foi feita verificação nominal dos 1834 sujeitos na repartição do Governo, no registros.

Dos resultados conseguidos:

1. Fez-se descrição sucinta do desenvolvimento da enfermagem no País, e do início dos serviços públicos de saúde. 
2. Como pessoal de enfermagem, incluídos atendentes, foram encontrados: nos hospitais, 1340 pessoas em serviço, sendo $8 \%$ enfermeiras, $18 \%$ obstetrizes de grau médio, auxiliares e práticos de enfermagem, e 74\% atendentes; nos ambulatórios e unidades sanitárias foram encontradas 494 pessoas, sendo $5 \%$ enfermeiros, $34 \%$ auxiliares e práticos de enfermagem e $61 \%$ atendentes.

3. Quanto a enfermeiros responsáveis pelo serviço de enfermagem, foram encontrados: nos hospitais de governo: em $83,3 \%$ dos hospitais; nos hospitais particulares sem fins lucrativos, em nenhum deles.

4. Quanto a salários, todo o pessoal, de modo geral, tinha salário relativamente baixo, comparado a nível de responsabilidade, grau de dificuldade e requisitos legais.

5. Quanto às obstetrizes do Recife, a moda e mediana de seus salários as situaram abaixo de todas as ocupações médicas de enfermagem, inclusive de parteiras práticas, enquanto suas funções, atribuídas por lei, são superiores às do pessoal citado.

6. Os atendentes mostraram 42 variações salariais, a sugerir necessidade de ajustamento dessa categoria quanto a consenso de suas atribuições e revisão dos requisitos para exercício. Ficou evidente $o$ avanço do atendente, no Recife, para a faixa de atribuições de outras ocupações de enfermagem, inclusive do enfermeiro.

7. É da maior importância para a compreensão da pouca difusão da enfermagem moderna o estudo da Universidade e do cumprimento de seu papel no desenvolvimento do País (Cap. VIII).

8. Em apenas um (1), dentre os trinta e seis (36) hospitais investigados havia normas regimentais assegurando institucionalização do órgão, e serviço de enfermagem, chefiado por enfermeiro.

9. Os enfermeiros conseguiram institucionalizar, em parte, o exercício de sua profissão técnico-científica. Falta-lhes entre outras uma parte importante, - a que se preste a registro documentário para fins não só de prática profissional como também de controle. Falta-lhes o plano de cuidado (final da tese). 